ISSN: 0215-7950

\title{
Identifikasi Spesies Meloidogyne spp. Penyebab Umbi Bercabang pada Tanaman Wortel di Jawa Timur
}

\author{
Species Identification of Meloidogyne spp., the Cause of \\ Branched Tuber Disease in Carrot in East Java
}

\author{
Zalzilatul Hikmia*, Supramana, Gede Suastika \\ Institut Pertanian Bogor, Bogor 16680
}

\begin{abstract}
ABSTRAK
Umbi bercabang merupakan penyakit baru dalam budi daya tanaman wortel di Indonesia dan telah menimbulkan kerugian yang besar bagi petani. Pada tahun 2010 beberapa spesies nematoda puru akar (NPA), Meloidogyne spp., dilaporkan sebagai penyebab utama penyakit umbi bercabang pada wortel di wilayah Agropolitan-Cianjur, Jawa Barat. Kerugian yang ditimbulkan berkisar antara 15\% dan 95\%. Gejala umbi bercabang juga telah dilaporkan pada salah satu sentra produksi sayuran di Jawa Timur, yaitu di wilayah Desa Sumber Brantas, Kecamatan Bumiaji, Kota Batu. Penelitian ini bertujuan mengidentifikasi spesies Meloidogyne spp. penyebab umbi bercabang pada wortel. Penelitian terdiri atas dua kegiatan, yaitu survei dan identifikasi. Survei dilakukan di Desa Sumber Brantas, Kecamatan Bumiaji, Kota Batu pada tiga ketinggian, yaitu $1600 \mathrm{~m}, 1700 \mathrm{~m}$, dan $1800 \mathrm{~m}$ di atas permukaan laut. Identifikasi spesies NPA dilakukan dengan pendekatan biomolekul PCR ITS r-DNA menggunakan primer multipleks untuk mengidentifikasi campuran spesies M. hapla, M. fallax, dan M. chitwoodi, dan 3 primer spesifik untuk mengidentifikasi spesies $M$. arenaria, M. incognita, dan M. javanica. Hasil identifikasi PCR ITS r-DNA secara positif mendeteksi empat spesies, yaitu M. arenaria, M. hapla, M. incognita, dan M. javanica.
\end{abstract}

Kata kunci: Daucus carota, Meloidogyne, PCR ITS r-DNA, penyakit umbi bercabang

\begin{abstract}
Branched tuber is a new disease in carrot cultivation in Indonesia and has caused big losses for farmers. In 2010, several species of root-knot nematodes, Meloidogyne spp., were reported as the primary cause of disease and the yield loss due to the disease in the region of Agropolitan-Cianjur, West Java, reached 15\% to $95 \%$. Symptoms of tuber branching has also been reported in one of the centers of vegetable production in East Java, in the subdistrict of Bumiaji, Kota Batu. Research aimed at identifying Meloidogyne species on carrot was carried out on carrot plantation. The study consisted of two activities, i.e. surveillance and identification. Surveillance was carried out at three different altitudes/elevations, i.e. $1600 \mathrm{~m}, 1700 \mathrm{~m}$ and $1800 \mathrm{~m}$ asl (above sea level). Identification was done by PCR ITS r-DNA using multiplex primer for mix spesies identification of M. hapla, M. fallax, and M. chitwoodi and the spesific primer for identification of $M$. arenaria, $M$. incognita, and $M$. javanica. Identification based on ITS r-DNA by PCR gave positive results for four species, namely M. hapla, M. arenaria, M. incognita, and M. javanica.
\end{abstract}

Key words: branched tuber disease, carrot, Meloidogyne, PCR ITS r-DNA

\footnotetext{
*Alamat penulis korespondensi: Departemen Proteksi Tanaman, Fakultas Pertanian, Institut Pertanian Bogor, Kampus IPB Darmaga, Jalan Kamper, Bogor 16680;

Tel: 0251-8629364, Faks: 0251-8629362, Surel: supramana@ipb.ac.id
} 


\section{PENDAHULUAN}

Umbi bercabang merupakan penyakit baru dalam budi daya tanaman wortel di Indonesia dan telah menimbulkan kerugian yang besar bagi petani. Kurniawan (2010) melaporkan beberapa spesies nematoda puru akar (NPA), Meloidogyne spp., sebagai penyebab utama penyakit umbi bercabang pada wortel di wilayah Agropolitan-Cianjur, Jawa Barat. Kerugian yang ditimbulkan berkisar antara 15\% dan 95\%. Taher et al. (2012) juga telah melaporkan gejala yang sama pada pertanaman wortel di daerah Dieng, Jawa Tengah.

Gejala malformasi umbi akibat serangan NPA dapat berupa umbi bercabang (forking) dan adanya puru (galling) (Taher et al. 2012). Penyakit ini menjadi salah satu masalah terbesar dalam budi daya wortel. Gejala serupa telah dilaporkan pula di sentra produksi sayuran di Jawa Timur, yaitu di Desa Sumber Brantas, Kecamatan Bumiaji, Kota Batu. Walaupun telah menjadi organisme pengganggu tanaman (OPT) utama, namun identifikasi spesies NPA belum dilakukan. Oleh karena itu, perlu identifikasi spesies NPA pada umbi wortel bercabang sebagai dasar dalam menyusun strategi pengendalian penyakit umbi bercabang wortel di lapangan yang efektif, efesien, dan ramah lingkungan.

\section{BAHAN DAN METODE}

\section{Survei}

Survei dilakukan pada beberapa kebun wortel di Desa Sumber Brantas yang terletak pada ketinggian $1600 \mathrm{~m}, 1700 \mathrm{~m}$, dan $1800 \mathrm{~m}$ dpl. Wortel yang digunakan sebagai sampel adalah umbi wortel yang menunjukkan gejala umbi bercabang. Sampel dililit kertas koran untuk menjaga suhu nematoda agar tetap stabil dan diletakkan dalam cooling box yang telah diberi es batu (Taher et al. 2012).

Pengamatan gejala penyakit difokuskan pada bagian perakaran tanaman. Gejala perakaran yang diamati berupa bentuk umbi, letak dan ukuran puru, dan keberadaan akar rambut.

\section{Identifikasi NPA Berdasarkan pada PCR ITS r-DNA}

Ekstraksi DNA nematoda dilakukan dengan mengekstraksi puru yang berada pada akar dan umbi terinfeksi NPA (Tesarova et al.2012). Puru digerus dengan mortar dan pistil, kemudian ditambahkan larutan bufer ekstrak $(50 \mathrm{mM}$ Tris $\mathrm{HCl} \mathrm{pH}$ 8.0, 0.7 M NaCl, $10 \mathrm{mM}$ EDTA, $1 \%$ CTAB) dan diinkubasi selama 2 jam pada suhu $60{ }^{\circ} \mathrm{C}$ pada pemanas air. Setiap 10 menit tabung mikro dibolak-balik untuk membantu proses lisis. Tabung mikro diambil dari pemanas air dan didinginkan sekitar 3-5 menit pada suhu ruangan, ditambah kloroform isoamilalkohol dengan perbandingan 1:1 terhadap bufer, selanjutnya tabung disentrifugasi selama 15 menit pada kecepatan 12000 rpm. Supernatan yang terbentuk diambil sebanyak $500 \mu \mathrm{L}$ dan dipindahkan ke dalam tabung mikro yang baru. Natrium asetat $3 \mathrm{M}(\mathrm{pH}$ 5.2) ditambahkan dengan perbandingan 1:10 dengan supernatan dan dicampur sampai homogen. Sebanyak $1 \mathrm{~mL}$ etanol ditambahkan dan dicampur ke dalam suspensi hingga homogen untuk presipitasi DNA. Tabung diinkubasi pada suhu $-20{ }^{\circ} \mathrm{C}$ selama 1 jam atau dibiarkan selama satu malam.

Selain menggunakan puru ekstraksi DNA NPA dilakukan terhadap nematoda betina dari NPA. Sekitar 10-20 nematoda betina yang telah dipisahkan dari akar dan puru dimasukkan ke dalam tabung mikro $2 \mathrm{~mL}$. Bufer ekstrak (200 mM Tris-HCl: pH 8.5, $250 \mathrm{mM} \mathrm{NaCl}$, $25 \mathrm{mM}$ EDTA dan SDS 0.5\%) dan $150 \mu \mathrm{L}$ DNA kemudian ditambahkan ke dalam tabung mikro yang berisi nematoda betina dan digerus dengan cornical grinder steril. Setelah homogen ditambahkan larutan sodium asetat $3 \mathrm{M}(\mathrm{pH}$ 5.2) 0.5 volume dan disimpan di lemari es pada suhu $-20{ }^{\circ} \mathrm{C}$ selama 10 menit.

Suspensi yang didapat dari puru dan nematoda betina masing-masing disentrifugasi pada kecepatan $12000 \mathrm{rpm}$ selama 10 menit. Cairan suspensi dibuang dan ditambah $200 \mathrm{~mL}$ etanol 70\% untuk mencuci pelet (endapan DNA), kemudian cairan pelet disentrifugasi dengan kecepatan 12000 rpm selama 5 menit. Cairan etanol dibuang dan endapan DNA dikeringanginkan dengan cara membalik 
tabung mikro. Bufer TE (10 mM Tris-HCl: $\mathrm{pH}$ 8.0, 1 mM EDTA) ditambahkan pada tabung mikro sesuai dengan ketebalan endapan DNA, pada endapan yang tipis sebanyak $30-40 \mu \mathrm{L}$ dan untuk endapan yang tebal 50-100 $\mu \mathrm{L}$.

Amplifikasi DNA dengan menggunakan primer spesifik dilakukan untuk $M$. incognita, yaitu MI-F (primer forward) dengan susunan nukleotida 5'-GTG AGG ATT CAG TCT CCCAG-3' dan MI-R (primer reverse) dengan susunan nukleotida 5'-ACG AGG AAC ATA CTT CTC CGT CC-3' (Meng et al. 2004); $M$. arenaria, dengan primer forward Far 5'-TCG GCG ATA GAG GTA AAT GAC-3' dan primer reverse Rar 5'-TCG GCG ATA GAC ACT ACA AAC T-3', dan M. javanica, menggunakan primer Fjav (primer forward) 5'-GGT GCG CGA TTG AAC TGA GC-3'dan Rjav (primer reverse) 5'-CAG GCC CTT CAG TGG AAC TAT AC-3' (Zijlstra et al. 2000). Deteksi $M$. hapla, M. falax, dan M. chitwoodi menggunakan primer multipleks, yaitu JMV1 5'-GGA TGG CGT GCT TTC AAC-3', JMV2 5'-TTT CCC CTT ATG ATG TTT ACC C-3', dan JMV-hapla 5'AAA AAT CC CTC GAAAAA TCC ACC-3' (Wishart et al. 2002).

Pereaksi PCR yang digunakan untuk setiap reaksi PCR yaitu $16.25 \mu \mathrm{L} \mathrm{ddH}_{2} \mathrm{O}, 2.5 \mu \mathrm{L}$ bufer Taq $10 \mathrm{x} \mathrm{Mg}^{2+}, 2.5 \mu \mathrm{L}$ sukrosa, $0.5 \mu \mathrm{L}$ dNTP $10 \mathrm{mM}, 1 \mu \mathrm{L}$ primer forward $10 \mu \mathrm{M}, 1 \mu \mathrm{L}$ primer reverse $10 \mu \mathrm{M}, 1 \mu \mathrm{L}$ DNA, dan $0.25 \mu \mathrm{L}$ Taq DNA polimerase sehingga total volume reaksi PCR menjadi $25 \mu \mathrm{L}$ (Hyman et al. 1997). Selanjutnya dilakukan amplifikasi pada mesin PCR (thermo cycler) dengan program denaturasi awal pada suhu $94{ }^{\circ} \mathrm{C}$ selama 4 menit, diikuti dengan 35 siklus yang meliputi denaturasi pada suhu $94{ }^{\circ} \mathrm{C}$ selama 30 detik, annealing pada suhu $57{ }^{\circ} \mathrm{C}$ selama 45 detik, pemanjangan pertama pada suhu $72{ }^{\circ} \mathrm{C}$ selama 1 menit, kemudian pemanjangan akhir pada suhu $72{ }^{\circ} \mathrm{C}$ selama 7 menit dan diakhiri dengan final hold pada suhu $4{ }^{\circ} \mathrm{C}$ selama 5 menit.

Hasil amplifikasi dianalisis untuk melihat DNA melalui elektroforesis menggunakan gel agarosa $1 \%$, dalam $40 \mathrm{~mL}$ bufer TBE (45 mM Tris $\mathrm{HCl}, 45 \mathrm{mM}$ asam borat, dan $1 \mathrm{mM}$ EDTA) dengan penambahan etidium bromida
$(0.5 \mu \mathrm{L}$ per $10 \mathrm{~mL})$. Pengukuran fragmen DNA menggunakan penanda $1 \mathrm{~kb}$ DNA ladder (Fermentas, United States of America). Sampel disiapkan dengan mencampur $8 \mu \mathrm{L}$ DNA dan $10 \mu \mathrm{L}$ loading buffer, kemudian sampel diisikan dalam sumuran gel sebanyak $5 \mu \mathrm{L}$ menggunakan pipet mikro. Elektroforesis dilakukan pada tegangan 50 volt DC selama 60 menit. Hasil elektroforesis divisualisasikan dengan transiluminator UV dan foto dengan kamera digital.

\section{HASIL}

\section{Deskripsi Lokasi}

Desa Sumber Brantas berada di Kecamatan Bumiaji, Kota Batu, Jawa Timur. Desa ini terletak pada ketinggian 1400 m-1700 m dpl dan suhu rata-rata $12-24{ }^{\circ} \mathrm{C}$. Wilayah ini diapit oleh beberapa gunung sehingga menjadikan Desa Sumber Brantas memiliki lahan yang subur. Potensi utama pertanian Desa Sumber Brantas adalah sayur-mayur. Tiga jenis sayuran yang menjadi komoditas utama ialah kentang, wortel, dan kubis.

\section{Gejala Penyakit di Lapangan}

Gejala infeksi NPA yang ditemukan di lapangan antara lain gejala umbi berambut, gejala umbi bercabang, dan gejala umbi bercabang berambut (Gambar 1). Pada gejala umbi berambut, umbi wortel tampak lebih besar, panjang dengan akar rambut menjuntai lebat disertai dengan puru akar. Puru akar kecil membulat seperti manikmanik pada sepanjang akar rambut (Gambar 1a). Pada gejala umbi bercabang, umbi wortel membentuk percabangan tanpa akar rambut. Percabangan umbi wortel tumbuh memanjang dengan 2-3 cabang (Gambar 1b). Pada gejala umbi bercabang dan berambut, umbi bercabang dengan banyak akar rambut dan percabangan terjadi lebih dari 2 cabang. Pada akar rambut terdapat puru, berbentuk kecil seperti manikmanik, berderet sepanjang perakaran. Umbi lebih pendek dan membengkak dibandingkan dengan umbi sakit pada dua gejala sebelumnya (Gambar 1c). 
Berdasarkan hasil pengambilan sampel umbi wortel sakit pada ketinggian 1600 m-1800 m dpl, ditemukan ketiga tipe umbi tersebut. Lokasi pengambilan sampel pertama pada ketinggian $1800 \mathrm{~m}$ dpl dengan suhu tanah $15{ }^{\circ} \mathrm{C}$, didominasi oleh gejala umbi berambut. Gejala umbi bercabang paling dominan pada lokasi kedua pada ketinggian $1700 \mathrm{~m}$ dpl dengan suhu tanah $18^{\circ} \mathrm{C}$; sedangkan pada lokasi ketiga pada ketinggian $1600 \mathrm{~m}$ dpl dengan suhu tanah $19{ }^{\circ} \mathrm{C}$ didominasi gejala umbi bercabang dan berambut.

Hasil pengamatan umbi wortel menunjukkan adanya lima tipe puru, yaitu tipe bulat pada akar rambut (hairy root), puru seperti kudis, puru seperti akar gada, puru memanjang, dan puru bulat berukuran besar $(>0.5 \mathrm{~cm})$ (Gambar 2). Hampir semua tipe puru ditemukan pada setiap ketinggian, kecuali puru yang berbentuk akar gada yang hanya ditemukan pada ketinggian $1600 \mathrm{~m}$ dpl. Setelah diamati lebih rinci, diketahui bahwa puru yang ditemukan pada tanaman wortel sakit pada umumnya terdapat pada akar rambut, akar, dan umbi (Gambar 3).

\section{Identifikasi NPA Berdasarkan pada PCR ITS r-DNA}

Identifikasi PCR dilakukan untuk mengetahui spesies NPA yang menginfeksi umbi tanaman wortel. Hasil identifikasi secara

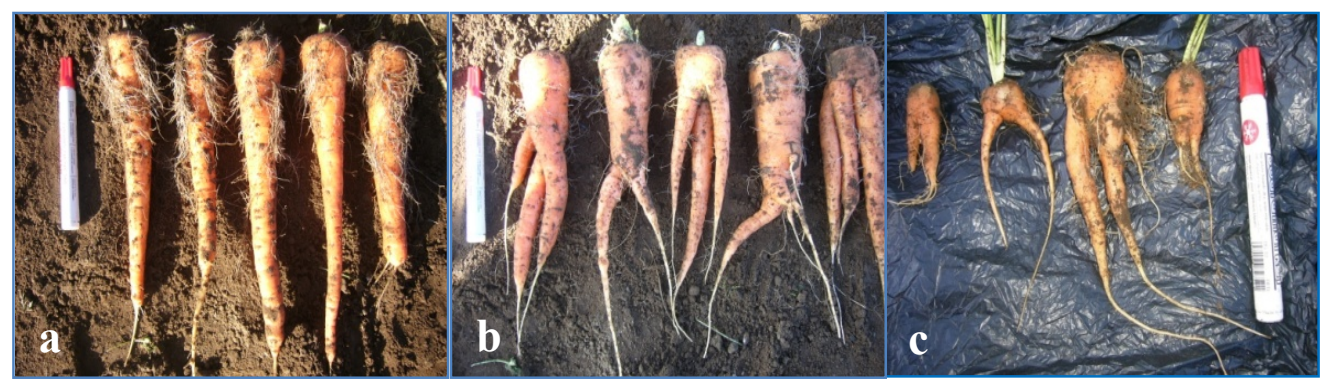

Gambar 1 Gejala umbi tanaman wortel terinfeksi nematoda puru akar: a, gejala umbi berambut; b, gejala umbi bercabang; c, gejala umbi bercabang dan berambut.

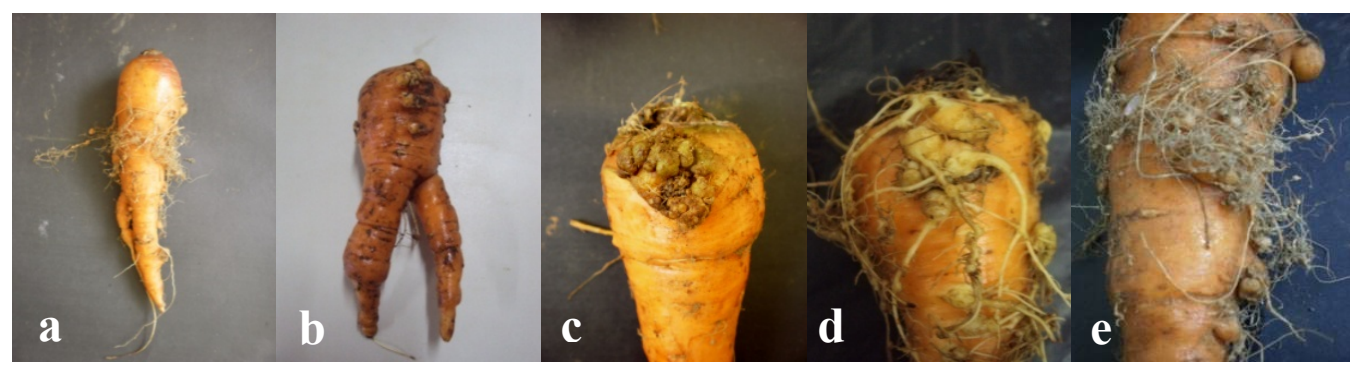

Gambar 2 Tipe puru pada perakaran wortel: a, puru bulat pada akar rambut; b, puru sepeti kudis; c, puru seperti akar gada; d, puru memanjang; e, puru bulat berukuran besar $(>0.5 \mathrm{~cm})$.

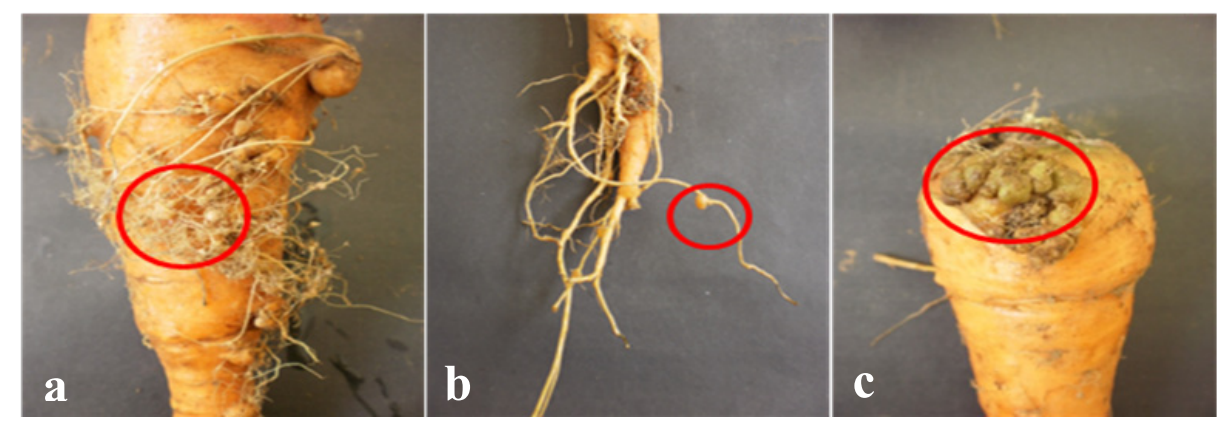

Gambar 3 Lokasi terbentuknya puru: a, pada akar rambut (hairy root); b, pada akar; c, pada umbi wortel. 

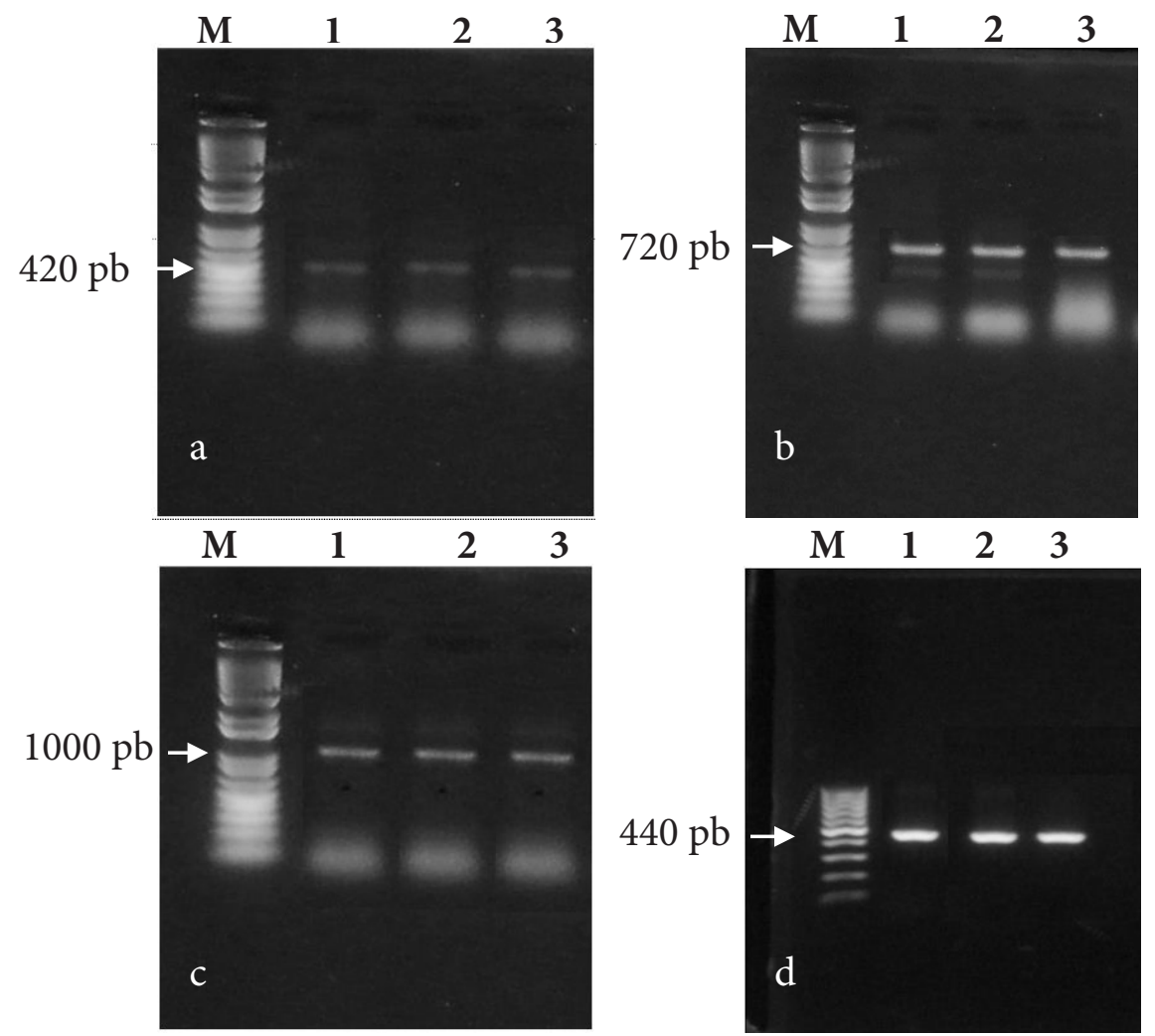

Gambar 4. Hasil amplifikasi DNA nematoda puru akar dari Desa Sumber Brantas, Jawa Timur menggunakan primer spesifik: a, Meloidognye arenaria; b, M. javanica; c, M. incognita; $M$. halpa. Sampel berasal dari ketinggian tempat yang berbeda: 1, ketinggian $1800 \mathrm{~m}$ dpl; 2, ketinggian 1700 m dpl; ketinggian 1600 m dpl. Panah menunjukkan ukuran DNA hasil amplifikasi.

positif mendeteksi empat spesies NPA, yaitu M. arenaria, M. hapla, M. incognita, dan $M$. javanica. $M$. arenaria berhasil terdeteksi dengan pita DNA berukuran $420 \mathrm{pb}$ (Gambar 4a), M. javanica pada $440 \mathrm{pb}$ (Gambar 4b), $M$. incognita pada $1000 \mathrm{pb}$ (Gambar 4c), dan $M$. halpa $720 \mathrm{pb}$ (Gambar 4d).

\section{PEMBAHASAN}

Secara umum infeksi NPA memiliki kesamaan gejala dengan yang dilaporkan oleh Kurniawan (2010) dan Taher et al. (2012). Umbi wortel yang terinfeksi NPA di Jawa Barat dan Jawa Tengah juga mengalami malformasi. Gejala malformasi pada kedua daerah tersebut berbeda dengan gejala malformasi yang ditemukan di daerah Jawa Timur. Gejala malformasi dikedua daerah tersebut dikelompokkan menjadi empat bentuk malformasi umbi, yakni umbi bercabang, umbi pendek membulat, umbi pecah, dan umbi berambut.
Selain malformasi umbi pada bagian umbi terdapat juga gejala berupa puru. Puru yang terbentuk sama dengan puru akibat infeksi $M$. hapla yang lebih kecil dan lebih membulat dibandingkan dengan puru yang disebabkan spesies NPA lain, yang cenderung lebih besar dan menyatu (Vrain 1982). Infeksi NPA yang tinggi pada umbi diduga menyebabkan umbi mengalami percabangan. Umbi baru yang terbentuk terjadi karena fungsi akar utama yang terganggu oleh infeksi NPA.

Hasil identifikasi PCR ITS r-DNA berhasil mendeteksi empat spesies NPA, yaitu $M$. arenaria, M. hapla, M. incognita, dan M. javanica. Hasil tersebut sama dengan hasil PCR yang telah dilakukan oleh Kurniawan (2010).

Tiga primer spesifik berhasil mengidentifikasi M. arenaria, M. incognita, dan M. javanica, sedangkan primer multipleks hanya berhasil mendeteksi satu spesies, yaitu M. hapla. Wishart et al. (2002) berhasil mengidentifikasi ketiga 
nematoda tersebut dengan menggunakan primer multipleks, dengan besar pita DNA yang sama.

Pada Gambar 4, 5, 6, dan 7 terlihat pita DNA dari tiap spesies yang berbeda ketebalannya, hal ini disebabkan oleh kadar DNA hasil ekstraksi setiap spesies yang berbeda-beda. Pengujian dengan pendekatan biologi molekul diyakini lebih cepat dan lebih akurat dibandingkan dengan identifikasi karakter morfologi dan pola sidik pantat (Kurniawan 2010).

Keempat spesies yang ditemukan pada penelitian ini juga ditemukan di daerah Jawa Tengah (Taher et al. 2012) dan Jawa Barat (Kurniawan 2010). Di daerah Jawa Barat, Kurniawan (2010) menemukan keberadaan spesies selain empat spesies tersebut, yaitu $M$. fallax. Berdasarkan hasil identifikasi spesies NPA yang telah dilakukan, strategi pengendalian umbi wortel bercabang di Jawa Timur dapat difokuskan terhadap $M$. arenaria, M. hapla, $M$. incognita, dan M. javanica.

\section{DAFTAR PUSTAKA}

Hyman B, Powers T, Harris T. 1997. Workshop: Molecular Approaches to Nematode Identification. Tucson (US): University of Arizona.

Kurniawan W. 2010. Identifikasi penyakit umbi bercabang pada wortel, Daucus carota (L.), di Indonesia [tesis]. Bogor (ID): Institut Pertanian Bogor.
Meng QP, Long H, Xu JH. 2004. PCR assay for rapid and sensitive identification of three major root-knoot nematodes, Meloidogyne incognita, M. javanica, and $M$. arenaria. Acta Phytopathol Sinica. 34(3):204-210.

Vrain TC. 1982. Relationship between Meloidogyne hapla density and damage to carrots in organic soil. J Nematol. 14(1):50-57.

Taher M, Supramana, Gede S. 2012. Identifikasi Meloidogyne penyebab penyakit umbi bercabang pada wortel di Dataran Tinggi Dieng. J Fitopatol Indones. 8(1):16-21.

Tesarova B. Zouhar M, P. Rysanek P. 2012 Development of species specific molecular method for detection of Meloidogyne incognita.http://www.fem.uniag.sk/acta/ download.php?id=191. [diakses 10 Juni 2012]

Wishart J, Phillips MS, Blok VC. 2002. Ribosomal intergenic spacer: a polymerase chain reaction diagnostic for Meloidogyne chitwoodi, Meloidogyne. fallax, and Meloidogyne. hapla. Phytopathology. 92(8): 884-892.

Zijlstra C, Donkers-Venne DTHM, Fargette M. 2000. Identification of Meloidogyne incognita, M. javanica and $M$. arenaria using sequence characterised amplified region (SCAR) based PCR assays. Nematology. 2(8):847-853. 